\title{
8. Financial well-being in basic income experiment
}

\author{
Maarit Lassander and Signe Jauhiainen
}

\section{INTRODUCTION}

The potential impact of income distribution on different aspects of well-being is a timely issue to consider when discussing the future of social policies in many European countries (Senik, 2009; Jakab, 2012; Blomgren et al., 2017) and current hardships facing these societies (Ståhl and MacEachen, 2020). Our aim in this chapter is to discuss how basic income is related to financial well-being. Basic income is often assumed to increase people's sense of security, intrinsic motivation, and empowerment when their monthly income is guaranteed, which in turn can affect various well-being outcomes (Forget, 2011).

Understanding the mechanisms and different aspects of financial well-being has also become increasingly important in societies where socially provided financial safety nets are lacking and where personal financial planning is needed, even in traditional welfare states (Smith, 2015). The burden of mental and physical ill-health lies on a significant percentage of population and the social costs of health inequities are rising (Jakab, 2012; Marmot et al., 2012). Income is considered the most important social determinant of health, and income inequality is associated with lower well-being, but the specific models of income distribution have been difficult to assess (Ngamaba et al., 2018). Financial problems at the individual level are reflected in communities in terms of safety and collective well-being (Layard et al., 2008). Basic income has been proposed to foster more cooperative, less competitive, interconnections within societies. These societies would be based on trusting and cooperative relationships, offering an antidote to increasing inequalities (Mays, 2019).

Better personal financial management can reduce credit risk and increase financial stability and employment productivity (Diener, 2000). Financial well-being has also been linked to individual experience of well-being (Van Praag et al., 2003; Kahn and Pearlin, 2006), whereas long-term indebtedness has been linked to depressive symptoms (Hojman et al., 2016) and the likeli- 
hood of early retirement (Blomgren et al., 2017). Stress caused by financial instability affects not only individuals but also families and communities, for example through decreasing labour productivity and increasing physical health problems (Kim and Garman, 2003).

A well-established theoretical framework for understanding financial well-being springs from Maslow's (1943) hierarchy of needs, which separates short-term acute needs (food and housing) from longer-term security enhancing needs (saving for retirement, investing in the family's future) (Xiao and Noring, 1994). This separation of needs is still useful, as it facilitates understanding of how financial difficulties can detract from considering long-term, more advanced goals. On the other hand, Maslow's hierarchy has been challenged in situations where individual values and priorities affect the order of hierarchical needs (Kenrick et al., 2010). In addition, not all approaches to financial well-being are needs-based. For example, standard of living surveys (Johansson, 1973) emphasise resources that add to material well-being. Measurement of well-being has involved two influential traditions (Diener and Biswas-Diener, 2002) that have focused on either: (1) objective well-being, i.e. resources enabling individuals to pursue their personal goals, e.g. access to housing, clean water, education, or reasonable income (Sen, 1993), and (2) the subjective experience of fulfilling one's needs (Erikson, 1993). A third perspective has been advocated by Sen (1993), who emphasised the role of basic capabilities and functioning, varying from good health to self-respect and social integration, as the basis of well-being.

Another theory that has been supported and replicated across numerous studies proposes that raising the income of all does not increase the happiness of all (Easterlin, 1995), and that men on low income seem to benefit most from an income increase (Zyphur et al., 2015). A third approach to financial well-being involves engaging with eight dimensions of wellness identified by Swarbrick and Yudof (2015), one of which is financial well-being specifically. The model used in that approach is based on the concept of physical and psychological wellness of individuals.

As discussed earlier, in Chapters 3 and 5, the Finnish basic income experiment was a randomised controlled trial (RCT) that has the potential to offer some indications of connections between intervention and measured variables, even if further research is needed to draw conclusions. To the best of our knowledge, the Finnish basic income experiment was the first national experiment with obligatory participation, which enables exploring the relationship between basic income and subjective financial well-being (SFWB). This study offers promising findings and motivates further research endeavours.

In this chapter, we discuss the following questions in relation to the Finnish basic income experiment: 


\section{How are unemployment and SFWB related?}

2 How did the receivers of basic income and the control group differ in their experience of $S F W B$ ?

In this chapter, we review previous literature on SFWB to provide an overview and we discuss how SFWB and basic income are related. Our empirical analysis focuses on Research Question 2. We analyse the difference in the experienced financial situation and subjective financial well-being between treatment and control groups. These indicators were measured in a survey conducted in autumn 2018. The survey data are described in more detail in Chapter 5. Owing to the low response rate and possible non-response bias, the data were re-weighed. The treatment and control groups in this chapter refer to those individuals in these groups who responded to the survey. In this chapter, we also utilise data derived from the administrative register of the Social Insurance Institution of Finland (Kela). This register contains information on receiving social assistance, which is an indicator of both low income and of having no savings. An individual is defined as a social assistance recipient if he or she is a member of a household that has received social assistance at least once during 2018.

Our results indicate that basic income may be related to subjective financial well-being and a person's experienced financial situation. However, we also acknowledge the potential psychological effect of being included in an experiment that attracted positive media attention (further discussed in Chapter 5). Nevertheless, our findings are in line with the results from the Canadian basic income experiment (e.g. Forget, 2011, 2013).

The structure of this chapter is as follows. We begin by defining the concept of SFWB, proceed to review previous relevant research, and discuss the financial well-being of the unemployed. We then analyse the experienced financial situation in treatment and control groups. We show the results of the SFWB indicators in treatment and control groups and validate the results in a regression analysis. Finally, we conclude and discuss our findings.

\section{DEFINING FINANCIAL WELL-BEING}

The measurement of subjective financial well-being (SFWB) reflects the development of subjective versus objective measures in the well-being literature. In recent decades, psychologists, economists, and social scientists have all become increasingly interested in subjective dimensions of well-being (SWB) (e.g. Veenhoven, 2002; Keyes, 2006; Layard et al., 2008). As the relationality of perceived well-being seems to be better captured with subjective measures, these measures have been gaining ground (Veenhoven, 2002; Keyes, 2006; Cooke et al., 2016), while it is still understood that certain basic 
levels of objective well-being (e.g. food and shelter) are necessary for SWB (Maslow, 1943; Sen, 1993; Diener and Biswas-Diener, 2002). Health status has been found to be strongly related to subjective well-being when examined using multidimensional measures in developed countries (WHO, 2008).

Some definitions of financial well-being utilise both objective and subjective indicators, and some focus on either objective or subjective well-being (Brüggen et al., 2017). Objective indicators provide information about the situation and subjective indicators measure an individual's evaluation of a situation. Self-reported evaluation is crucial when considering outcomes. Arber et al. (2014) demonstrated in a longitudinal study that SFWB mediates income-related health outcomes. Chou et al. (2016) proposed that SFWB is linked to physical pain mediated through a sense of control. Subjective measures enable individuals to evaluate the experience of their own financial situation through both cognitive and affective reactions (Diener, 1984). Subjective measures are also better equipped to examine non-financial effects (e.g. societal attitudes toward wealth). Individuals facing a similar financial situation can experience it in very different ways, depending on expectations, environment, social status, and opportunities. The need for financial security in any particular life stage and the ability to live with uncertainty are also noteworthy factors in relation to experienced well-being (Kim and Garman, 2003; Malone et al., 2010), and basic income may strengthen resilience in the face of adverse life events (Haagh, 2019).

There are a few definitions of financial well-being that have been proposed over the past decade. Brüggen et al. (2017) define financial well-being as the perception of being able to sustain current and anticipated desired living standards and financial freedom. A similar definition has been introduced by Netemeyer et al. (2018), dividing financial well-being in (1) a manageable level of stress over current finances, and (2) a sense of security about achieving future financial goals. Zyphur et al. (2015) conclude that financial well-being includes subjective financial stress, financial manageability, and future prospects. Chou et al. (2016) refer to financial well-being as involving experienced economic security in the present and in the foreseeable future. Based on these definitions, a consensus seems to exist that financial well-being can be defined by the subjective evaluation of (1) present financial situation (stress and manageability), and (2) future expectations. These notions appear to be linked to the discussion that has arisen around subjective well-being and the capabilities approach, focusing on the basic capabilities needed for living a reasonable life (Sen, 1993).

SFWB is influenced by demographic factors (age, gender, family structure and level of education) (Joo and Grable, 2004; Malone et al., 2010). Other factors to be noted are financial awareness and capability (Shim et al., 2009; Vosloo et al., 2014), financial attitudes (Norvilitis et al., 2003), personal traits 
and values (Gutter and Copur, 2011), and financial behaviour (Joo and Grable, 2004; Shim et al., 2009). Societal factors that can have an impact include the labour market situation, inflation, and interest rates (O'Neill et al., 2005). Personal and professional peer groups can also affect how individuals perceive their situation compared with others (Ferrer-i-Carbonell, 2005; Dolan et al., 2008). If the experience of financial well-being cannot be reduced to objective indicators (income level) or behavioural modes (financial management), we are then faced with the question of what should be measured.

\section{SFWB among the Unemployed}

The Finnish basic income experiment participants were long-term unemployed. Unemployment affects not only access to income but also mental health (Paul and Moser, 2009). Unemployment decreases life satisfaction and happiness (e.g., Winkelmann and Winkelmann, 1998; Lucas et al., 2004; Layard et al., 2008; Winkelmann, 2009) and several dimensions of well-being (e.g., Goul Andersen, 2002; Paul and Moser, 2009; Kunze and Suppa, 2017). It seems that the longer unemployment lasts, the more it affects well-being in terms of life satisfaction and psychological distress, and the effects may be permanent even if the individual in question is eventually employed (Goul Andersen, 2002; Knabe et al., 2010). Long-term unemployment also leads to a reduced likelihood of employment over time and adds to the disadvantages of vulnerable social groups. The risk of long-term unemployment is higher for low-skilled persons and occupations, single parents, migrants, and disabled persons. It has also been shown that women, older people, and permanently employed persons are more affected by long-term unemployment (Heidenreich, 2015).

SWB is highly sensitive to the effects of unemployment, leading to significant reduction (Brown et al., 2003), but there is no comparable evidence on SFWB. However, it is known that unemployment can severely decrease self-efficacy and effective decision-making as well as increase vulnerability to stress. In addition, the effect of income on well-being is greater at lower levels of income (Van Praag et al., 2003; Layard et al., 2008). Therefore, it is of paramount importance to find solutions that can enhance the SFWB of the unemployed, not only to promote better mental and physical health but also to increase the likelihood of meaningful employment in the future.

\section{RESULTS}

\section{Experienced Financial Situation}

In our survey, basic income recipients and members of the control group were asked how they experienced their household's income nowadays. The given 
alternatives were: (1) living comfortably, (2) coping, (3) finding it difficult, and (4) finding it very difficult on present income. The question was phrased similarly to that in the European Social Survey (ESS) to enable comparison with a representative sample. The outcomes and comparative data are presented in Table 8.1.

The basic income recipients experienced their financial situation as better than those in the control group when the whole sample was analysed. Of the basic income recipients, 13 percent felt that they were living comfortably and 47 percent felt that they were coping. Of the control group, 8 percent felt that they were living comfortably and 44 percent felt that they were coping. A total of 40 percent of the basic income recipients had some level of difficulty getting by compared with 48 percent among the control group members.

In the linked data, we were able to analyse two sub-groups according to their receipt of social assistance. It was necessary to examine these two groups separately since the proportion of social assistance recipients was smaller in the treatment group ( 29 percent) than in the control group (43 percent). Social assistance recipients encounter financial difficulties more often than those who do not receive social assistance. A significant difference between the basic income recipients and those in the control group was observed in the sub-group not receiving social assistance. The difference between the treatment and control groups was very small when social assistance recipients were compared. In fact, the basic income recipients seemed to evaluate their financial situation as very difficult slightly more often than those in the control group. The proportion of those who stated that, on their income, life was difficult or very difficult was nearly the same.

Comparative data from the Finnish sample of the ESS are presented in Table 8.1. In the ESS data, financial difficulties were reported as less frequent than in our survey data. The financial situation of the basic income recipients and those in the control group resembled the situation of the unemployed looking for jobs.

\section{Measuring SFWB in the Basic Income Experiment}

In line with the definitions of SFWB discussed, we examined the subjective experience of financial stress, the current financial management, evaluation of the capability to make rational financial decisions (financial freedom), and preparedness in terms of financial emergency funds (securing future). These measures are loosely based on the Swarbrick and Yudof (2015) dimension of financial wellness. Little is known concerning the effects of basic income on SWB in relation to public health, even if such effects might be considered potentially more consistent than labour market effects (Gibson et al., 2020). 
Table $8.1 \quad$ Proportions of self-reported feeling about household's income nowadays

\begin{tabular}{|c|c|c|c|c|c|}
\hline & $\begin{array}{r}\text { Social } \\
\text { assistance }\end{array}$ & $\begin{array}{r}\text { Living } \\
\text { comfortably } \\
(\%)\end{array}$ & $\begin{array}{r}\text { Coping } \\
(\%)\end{array}$ & $\begin{array}{r}\text { Finding it } \\
\text { difficult } \\
(\%)\end{array}$ & $\begin{array}{r}\text { Finding it very } \\
\text { difficult } \\
(\%)\end{array}$ \\
\hline Treatment group & & 13 & 47 & 28 & 12 \\
\hline Control group & & 8 & 44 & 32 & 15 \\
\hline \multicolumn{6}{|l|}{$n=1614$} \\
\hline Treatment group & Yes & 6 & 34 & 34 & 26 \\
\hline Control group & Yes & 5 & 33 & 41 & 21 \\
\hline Treatment group & No & 16 & 53 & 25 & 7 \\
\hline Control group & No & 11 & 52 & 27 & 10 \\
\hline \multicolumn{6}{|l|}{$n=1524$} \\
\hline \multicolumn{6}{|l|}{ ESS 2018} \\
\hline All & & 29 & 59 & 9 & 3 \\
\hline Paid work & & 34 & 58 & 7 & 1 \\
\hline $\begin{array}{l}\text { Unemployed, } \\
\text { looking for job }\end{array}$ & & 17 & 45 & 25 & 14 \\
\hline $\begin{array}{l}\text { Unemployed, not } \\
\text { looking for job }\end{array}$ & & 12 & 34 & 23 & 32 \\
\hline
\end{tabular}

There is some evidence of the effects of basic income on subjective well-being. The data analysed 30 years after collection showed that basic income had significant effects on the use of mental health services and accident-related health visits, which decreased by 10 percent (Forget, 2011, 2013). In an unconditional cash transfer experiment in Malawi, schoolgirls were 38 percent less likely to experience psychological distress than those in the control group (Baird et al., 2011). Studies from sub-Saharan Africa also point to some moderately positive health and quality of life outcomes (Owusu-Addo et al., 2018), with an ongoing experiment in Kenya currently being reviewed to assess the effects of basic income on depression. These findings have yet to be replicated, and there are no similar studies available on the effects of basic income on SFWB. 
This is in an unchartered territory of research, which is likely to become of increasing interest.

The findings concerning SFWB obtained from the Finnish basic income experiment are presented in Table 8.2. Most respondents were at least occasionally stressed over finances. This was unsurprising, considering that the participants were mainly receiving a low income.

Table 8.2 Response proportions of subjective financial well-being (SFWB) in the treatment and control groups

\begin{tabular}{|c|c|c|c|c|c|c|}
\hline & Group & $\begin{array}{r}\text { Never } \\
(\%)\end{array}$ & $\begin{array}{r}\text { Rarely } \\
(\%)\end{array}$ & $\begin{array}{r}\text { Sometimes } \\
(\%)\end{array}$ & $\begin{array}{r}\text { Always } \\
(\%)\end{array}$ & $\begin{array}{l}\chi^{2} \text {-test, } \\
p \text {-value }\end{array}$ \\
\hline \multirow[t]{2}{*}{ I have financial worries. } & Treatment & 14 & 13 & 47 & 26 & 0.011 \\
\hline & Control & 11 & 13 & 41 & 34 & \\
\hline My financial situation is & Treatment & 1 & 6 & 20 & 72 & 0.000 \\
\hline $\begin{array}{l}\text { under control and I can pay } \\
\text { my bills on time. }\end{array}$ & Control & 4 & 12 & 25 & 59 & \\
\hline I can make reasonable & Treatment & 20 & 24 & 35 & 21 & 0.059 \\
\hline financial decisions. & Control & 23 & 29 & 30 & 18 & \\
\hline \multirow[t]{2}{*}{ I have an emergency fund. } & Treatment & 41 & 13 & 18 & 27 & 0.006 \\
\hline & Control & 47 & 16 & 17 & 20 & \\
\hline
\end{tabular}

When comparing the basic income recipients and the control group, we noticed that in terms of financial stress, the basic income recipients seemed to be significantly less stressed by financial matters, but the differences were small (after combining the sometimes/always response categories for the basic income group (73 percent) and the control group (75 percent)). Among the basic income recipients, 26 percent reported being always worried about financial matters, whereas, among the control group, the figure was 34 percent. Many respondents in both groups (47 percent of the basic income recipients and 41 percent of the control group) were sometimes worried about financial matters. A total of 14 percent of the basic income recipients were never worried about financial matters compared with 11 percent of the control group.

Financial distress/stress has been contrasted with SFWB in some studies, but it is worth noting that it is a far more specific concept. Financial stress refers to the current situation where an individual finds it difficult to meet external financial expectations (Kim and Garman, 2003). The subjective experience of financial stress is strongly associated with many health problems (Arber et al., 2014), and financial difficulties cause more stress than many other everyday 
problems (Kahn and Pearlin, 2006). The outcomes of stress include problems in executive functioning and attention disorders, which can negatively affect financial decision-making and planning (O'Neill et al., 2005). Long-term stress can also increase reactivity to other stressors in life, magnifying the effects of, for example, divorce or relationship problems and lead to further negative financial outcomes (Kim and Garman, 2003). Long-term stress also affects the formation of memories, and - especially in older age groups memory difficulties are common when the lifetime stress burden is high (Kahn and Pearlin, 2006).

Financial behaviour is regarded as comprising a group of behaviours that have a direct effect on a person's financial situation, and which can be evaluated using either objective or subjective measures. Examples of the relevant kinds of behaviours are paying bills, saving, investing, budget management, spending, and debt management. Financial management can be measured in terms of whether a respondent feels he or she has the possibility of engaging in positive financial behaviour (e.g. paying bills by the due date). After comparing the basic income recipients to the control group recipients, we noticed that the basic income recipients seemed more capable of paying their bills on time and more in control of their finances, but again the differences were small when the sometimes/always categories were combined (the basic income group 92 percent and 84 percent for control group. A majority (72 percent) of the basic income recipients felt that they were always in control of their finances compared with 59 percent of the control group, whereas 7 percent of the basic income recipients and 16 percent of the control group felt they lacked control of their finances.

Financial management is associated with financial capability and financial behaviour. Financial capability (Vosloo et al., 2014) refers to an individual's ability to manage daily finances and enhance financial security. SFWB may increase the experience of capability and vice versa. Certain financial behaviours (e.g. paying bills, saving, investing, and budget management) can be either positive and stabilising, or negative and risk inducing. Interventions that target financial well-being often aim to make a positive change in some form of financial behaviour. Behaviour is also tied to a context, and the same behaviour in different contexts has different meanings. Researchers have debated the importance of financial literacy and basic financial skills, and how these skills are transmitted through parental and formal education. It is no doubt important that certain basic skills are developed, even if it is unclear how much they affect financial behaviour (Willis, 2011).

Financial management concerns the experience of control and the potential to engage in positive financial behaviour (paying bills on time). When comparing the treatment group to the control group, we found that the basic income 
recipients were more often able to pay their bills on time and more frequently believed that their financial situation was under control.

Financial freedom refers to individual possibilities to make reasonably independent financial decisions that are not coerced or that cause an unreasonable amount of stress (Brüggen et al., 2017). We asked respondents about their ability to make financially rational decisions, and the responses showed the least differences between the study groups, with 21 percent of the basic income recipients indicating that felt they had that ability compared with 18 percent of the control group.

In line with other measures of SFWB, a greater number of the basic income recipients ( 27 percent) felt that they had a financial backup (i.e. a financial emergency fund) than those in the control group ( 21 percent). It is also worth noting that over 40 percent in both groups felt that they never had any financial backup.

These findings accord with reported Finnish trends concerning savings, which show a considerable decrease in the last ten years (for details, please see the statistics from the Bank of Finland, 2008-18). Financial backup requires the opportunity to save, so that acute and unexpected costs can be covered. The size of any backup was not determined as the question aimed to measure preparedness for the future in general.

\section{Measures of SFWB in Regression Analysis}

The basic income recipients' income might have been higher than that of the control group although the data are re-weighted. Therefore, previously observed differences in SFWB might have been due to such income differences. In addition, SFWB is related to the financial situation of the whole household and includes the income and expenses of all household members. The relationship of basic income and SFWB was analysed in a regression analysis in which possible differences in income were controlled for. The categorical alternatives of SFWB were recoded into a dummy variable. The alternative 'always' was coded as 1 and the other alternatives as 0 . The survey data and register data were linked, and thus, we were able to utilise the receipt of social assistance in 2018 as an additional control variable. The receipt of social assistance was indicative of low household income and no savings. The coefficients for the receipt of basic income and its statistical significance in relation to SFWB are reported in Table 8.3.

The results are consistent with previous descriptive findings. The receipt of basic income was negatively related to having financial worries and positively related to financial management, financial freedom, and having an emergency fund. The coefficients in relation to having financial concerns, engaging in 
financial management, and having an emergency fund were also statistically significant when the receipt of social assistance was controlled for.

Table 8.3 Regression analysis results on subjective financial well-being $(S F W B)$

\begin{tabular}{lrr}
\hline & $\begin{array}{r}\text { Coefficient } \\
\text { Basic income }\end{array}$ & $p$-value \\
\hline I have financial worries. & -0.066 & $0.014 *$ \\
My financial situation is under control & 0.108 & $0.000 * * *$ \\
and I can pay my bills on time. & & \\
I can make reasonable financial & 0.032 & 0.174 \\
decisions. & & $0.009 * *$ \\
I have an emergency fund. & 0.063 & 0.09 \\
\hline
\end{tabular}

Note: Explanatory variables: treatment indicator (receiving basic income) and social assistance. Statistical significance: $* p$-value $<0.05, * * p$-value $<0.01, * * * p$-value $<0.001$

\section{CONCLUSIONS}

This chapter adds to the ongoing discussion on basic income (e.g. Van Parijs and Vanderborght, 2017) in proposing that examining the labour implications and cost-effectiveness of basic income from a productivity standpoint paints an incomplete picture. Other elements involved in income distribution that have significant influencing potential need to be considered to improve the well-being of those involved and their capacity to take part in and function in society as valued members. In other words, a combined perspective is needed that links SFWB and objective financial well-being, psychology, and economics, to widen the perspective on what is required for an effective, health-promoting life. The results presented provide a multidisciplinary account of how basic income can affect SFWB that is likely to be of value when used in making policy recommendations.

The basic income experiment and survey study aimed to examine whether a basic income had a specifically determinable effect on recipients' SFWB. We found that in all aspects of SFWB, the basic income recipients reported a higher SFWB and a better financial situation than those in the control group, but that in terms of stress and financial management, the differences were more subtle. When the receipt of social assistance was controlled for, the basic income recipients reported being less often worried, having better financial management, and being more often in possession of financial backup. The amount received in relation to basic income and the unemployment benefit was the same; however, the basic income recipients may have had a slightly 
higher income. The register data showed that the basic income recipients were employed on average just a few days more than those in the control group (Hämäläinen et al., 2020) and that the survey respondents in the treatment group received less social assistance (previously in this chapter). It is important to note that the benefit level did not change for the basic income experiment participants; they did not receive less than they had previously. Ensuring equality in terms of the amount received allowed for an evaluation of the effects of income structure. It has long been established within socio-economic research that people are attached to the status quo, and that loss of income tends to render people more unhappy than loss of potential gain (Van Praag et al., 2003; Layard et al., 2006).

In all public policy interventions where a sample of a population is subjected to an intervention of some kind, an issue arises concerning expectations and adaptation, which is also highly relevant to basic income experiments. Adaptation to increasing income will happen gradually; therefore, expectations are also more likely to rise with a rise in income, leading to a 'hedonic treadmill' (Van Praag et al., 2003; Layard et al., 2006). When life changes and the change leads to adaptation, this new state of things becomes the norm and expectations rise accordingly, which would leave SFWB mostly unaffected. A variation of adaptation is described in set point theory where it is suggested that an individual's well-being adapts to life changes and returns to a certain set-point of well-being determined by individual temperament (Brickman and Campbell, 1971) or more recently argued as set-range of well-being (Boehm and Lyubomirsky, 2009). Some life events, such as unemployment, are less easy to adapt to, possibly because they are closely related to everyday income and survival (Lucas et al., 2004). It seems that the SFWB of the basic income participants did not show evidence of adaptation over two years, which may indicate that basic income may have the potential to alleviate the negative effects of unemployment.

In previous research, it has been suggested that individuals who are satisfied with their income levels evaluate their income levels as higher than those who are unsatisfied with their income, despite the objective income levels involved (Prati, 2017). In other words, it is possible that SFWB rose in the basic income group, even when the objective income levels remained the same. It is also possible that the basic income recipients compared their situation favourably with the control group receiving unemployment benefits. When an income is compared with a reference group, the satisfaction on individual income is greatly affected by the income of that group, although there are individual differences. The effect of relative comparisons tends to be larger when comparisons involve similar types of individuals of the same age in the respective groups (Layard et al., 2008), and the potential effect of such comparisons still needs to be acknowledged. Stressors are associated with individual per- 
spectives and attitudes, so even if an income level stays the same, a change in income structure may cause positive reactions. The affective evaluation of one's participation in an experiment aimed at simplifying and facilitating benefit transfers could also have positively altered individual SFWB.

Previous research (Finke et al., 2017) has found that people are inclined to see the future in a more positive light than their present situation. Positive future evaluations and the extent to which one believes one can influence one's future can motivate one to act in a way that improves one's personal financial situation (Summerville and Roese, 2008). It is noteworthy, especially considering the current volatile financial situation, that a large group of people indicated that they did not have any financial backup to prepare them for financial setbacks. Any intervention that could facilitate saving to improve short-term preparedness would appear to worth pursuing.

We suggest that basic income as a regular and predictable income transfer may enhance SFWB through facilitating individual financial management and decreasing financial stress. Reducing financial stress may improve executive functioning and consequently improve financial decision-making. This, in turn, can enhance the experience of financial self-efficacy. Long-term stress (especially caused by financial difficulties) is associated with learned helplessness, hopelessness, and inactivity, and is also considered a risk factor for depression and anxiety disorders.

SFWB affects physical and psychological health, family relations, quality of life, and happiness (French and Vigne, 2019). At the same time, it is important to note that SFWB is a fluctuating experience. Positive expectations of future financial opportunities may ease the stress of present difficulties. On the other hand, bleak prospects can be profoundly distressing. Individual hopes and expectations change during life as do societal realities. The dynamic interplay between these factors should be considered when SFWB is measured.

\section{REFERENCES}

Arber, S., Fenn, K. and Meadows, R. (2014), 'Subjective financial well-being, income and health inequalities in mid and later life in Britain', Social Science and Medicine, 100, 12-20.

Baird, S., McIntosh, C. and Özler, B. (2011), 'Cash or condition? Evidence from a CashTransfer experiment', The Quarterly Journal of Economics, 126(4), 1709-53.

Blomgren, J., Maunula, N. and Hiilamo, H. (2017), 'Do debts lead to disability pension? Evidence from a 15-year follow-up of 54,000 Finnish men and women', Journal of European Social Policy, 27(2), 109-22.

Boehm, J. K. and Lyubomirsky, S. (2009), 'The promise of sustainable happiness', in Lopez, S. J. and Snyder, C. R. (eds), Oxford Library of Psychology. Oxford Handbook of Positive Psychology. Oxford: Oxford University Press. 
Brickman, P. and Campbell, D. T. (1971), 'Hedonic relativism and planning the good society', in Appley M. H. (ed.), Adaptation-level Theory. New York: Academic Press.

Brown, D. W., Balluz, L. S., Ford, E. S., Giles, W. H., Strine, T. W., Moriarty, D. G., Croft, J. B. and Mokdad, A. H. (2003), 'Associations between short- and long-term unemployment and frequent mental distress among a national sample of men and women', Journal of Occupational and Environmental Medicine, 45 (11), 1159-66.

Brüggen, E. C., Hogreve, J., Holmlund, M., Kabadayi, S. and Löfgren, M. (2017), 'Financial well-being: A conceptualization and research agenda', Journal of Business Research, 79, 228-37.

Chou, E. Y., Parmar, B. L. and Galinsky, A. D. (2016), 'Economic insecurity increases physical pain', Psychological Science, 27(4), 443-54.

Cooke, P. J., Melchert, T. P. and Connor, K. (2016), 'Measuring well-being: A review of instruments', The Counseling Psychologist, 44(5), 730-57.

Diener, E. (1984), 'Subjective well-being', Psychological Bulletin, 95(3), 542-75.

Diener, E. (2000), 'Subjective well-being: The science of happiness and a proposal for a national index', American Psychologist, 55(1), 34-43.

Diener, E. and Biswas-Diener, R. (2002), 'Will money increase subjective well-being?', Social Indicators Research, 57(2), 119-69.

Dolan, P., Peasgood, T. and White, M. (2008), 'Do we really know what makes us happy? A review of the economic literature on the factors associated with subjective well-being', Journal of Economic Psychology, 29(1), 94-122.

Easterlin, R. A. (1995), 'Will raising the incomes of all increase the happiness of all?', Journal of Economic Behavior and Organization, 27(1), 35-47.

Erikson, R. (1993), 'Descriptions of inequality: The Swedish approach to welfare research', in Sen, A. and Nussbaum, M. C. (eds), The Quality of Life. Oxford: World Institute for Development Economics Research, Clarendon Press, pp. 67-84.

Ferrer-i-Carbonell, A. (2005), 'Income and well-being: An empirical analysis of the comparison income effect', Journal of Public Economics, 89(5-6), 997-1019.

Finke, M. S., Howe, J. S. and Huston, S. J. (2017), 'Old age and the decline in financial literacy', Management Science, 63(1), 213-30.

Forget, E. L. (2011), 'The town with no poverty: The health effects of a Canadian guaranteed annual income field experiment', Canadian Public Policy, 37(3), 283-305.

Forget, E. L. (2013), 'Paying people to be healthy', International Journal of Health Policy and Management, 1(4), 245-6.

French, D. and Vigne, S. (2019), 'The causes and consequences of household financial strain: A systematic review', International Review of Financial Analysis, 62, 150-6.

Gibson, M., Hearty, W. and Craig, P. (2020), 'The public health effects of interventions similar to basic income: A scoping review', Lancet Public Health, 5 (3), e165-e176.

Goul Andersen, J. (2002), 'Coping with long-term unemployment: Economic security, labour market integration and well-being. Results from a Danish panel study, 1994-1999', International Journal of Social Welfare, 11(3), 178-90.

Gutter, M. and Copur, Z. (2011), 'Financial behaviors and financial well-being of college students: Evidence from a national survey', Journal of Family and Economic Issues, 32(4), 699-714.

Haagh, L. (2019), The Case for Universal Basic Income. Cambridge: Polity Press.

Heidenreich, M. (2015), 'The end of the honeymoon: The increasing differentiation of (long-term) unemployment risks in Europe', Journal of European Social Policy, 25(4), 393-413. 
Hojman, D. A., Miranda, Á and Ruiz-Tagle, J. (2016), 'Debt trajectories and mental health', Social Science and Medicine, 167(C), 54-62.

Hämäläinen, K., Kanninen, O., Simanainen, M. and Verho, J. (2020), Perustulokokeilun arvioinnin loppuraportti: Rekisterianalyysi työmarkkinavaikutuksista [Final Report of the Finnish Basic Income Experiment: Register Data Analysis on Employment Effects]. Helsinki: VATT Institute Economic Research, VATT Muistiot 59.

Jakab, Z. (2012), 'Promoting health and reducing health inequities in Europe', Lancet, 380(9846), 951-3.

Johansson, S. (1973), 'Review symposium on the 1968 level of living survey in Sweden: The level of living survey: A presentation', Acta Sociologica, 16(3), 211-24.

Joo, S. and Grable, J. E. (2004), 'An exploratory framework of the determinants of financial satisfaction', Journal of Family and Economic Issues, 25(1), 25-50.

Kahn, J. R. and Pearlin, L. I. (2006), 'Financial strain over the life course and health among older adults', Journal of Health and Social Behavior, 47(1), 17-31.

Kenrick, D. T., Griskevicius, V., Neuberg, S. L. and Schaller, M. (2010), 'Renovating the pyramid of needs: Contemporary extensions built upon ancient foundations', Perspectives on Psychological Science: A Journal of the Association for Psychological Science, 5(3), 292-314.

Keyes, C. L. M. (2006), 'Subjective well-being in mental health and human development research worldwide: An introduction', Social Indicators Research, 77(1), $1-10$.

Kim, J. and Garman, E. T. (2003), 'Financial stress and absenteeism: An empirically derived model', Journal of Financial Counseling and Planning, 14(1), 31-42.

Knabe, A., Rätzel, S., Schöb, R. and Weimann, J. (2010), 'Dissatisfied with life but having a good day: Time-use and well-being of the unemployed', The Economic Journal, 120(547), 867-89.

Kunze, L. and Suppa, N. (2017), 'Bowling alone or bowling at all? The effect of unemployment on social participation', Journal of Economic Behavior and Organization, $133,213-35$.

Layard, R., Mayraz, G. and Nickell, S. (2008), 'The marginal utility of income', Journal of Public Economics, 92(8-9), 1846-57.

Lucas, R. E., Clark, A. E., Georgellis, Y. and Diener, E. (2004), 'Unemployment alters the set point for life satisfaction', Psychological Science, 15(1), 8-13.

Malone, K., Stewart, S. D., Wilson, J. and Korsching, P. F. (2010), 'Perceptions of financial well-being among American women in diverse families', Journal of Family and Economic Issues, 31(1), 63-81.

Marmot, M., Allen, J., Bell, R., Bloomer, E., Goldblatt, P. and Consortium for the European Review of Social Determinants of Health and the Health Divide (2012), 'WHO European review of social determinants of health and the health divide', The Lancet, 380(9846), 1011-29.

Maslow, A. H. (1943), 'A theory of human motivation', Psychological Review, 50(4), 370-96.

Mays, J. (2019), 'Social effects of basic income', in Torry, M. (ed.), The Palgrave International Handbook for Basic Income: Exploring the Basic Income Guarantee. Houndmills, Basingstoke: Palgrave Macmillan pp. 73-90.

Ngamaba, K. H., Panagioti, M. and Armitage, C. J. (2018), 'Income inequality and subjective well-being: A systematic review and meta-analysis', Quality of Life Research: An International Journal of Quality of Life Aspects of Treatment, Care and Rehabilitation, 27(3), 577-96. 
Netemeyer, R. G., Warmath, D., Fernandes, D. and Lynch, J. G. (2018), 'How Am I Doing? Perceived financial well-being, its potential antecedents, and its relation to overall well-being', Journal of Consumer Research, 45(1), 68-89.

Norvilitis, J. M., Szablicki, P. B. and Wilson, S. D. (2003), 'Factors influencing levels of credit-card debt in college students', Journal of Applied Social Psychology, 33(5), 935-47.

O'Neill, B., Sorhaindo, B., Xiao, J. and Garman, E. (2005), 'Financially distressed consumers: Their financial practices, financial well-being, and health', Journal of Financial Counseling and Planning, 16(1), 73-87.

Owusu-Addo, E., Renzaho, A. M. N. and Smith, B. J. (2018), 'The impact of cash transfers on social determinants of health and health inequalities in sub-Saharan Africa: A systematic review', Health Policy and Planning, 33(5), 675-96.

Paul, K. I. and Moser, K. (2009), 'Unemployment impairs mental health: Meta-analyses', Journal of Vocational Behavior, 74(3), 264-82.

Prati, A. (2017), 'Hedonic recall bias. Why you should not ask people how much they earn', Journal of Economic Behavior and Organization, 143, 78-97.

Sen, A. (1993), 'Capability and well-being', in Sen, A. and Nussbaum, M. C. and World Institute for Development Economics Research (eds.), The Quality of Life. Oxford: Clarendon Press.

Senik, C. (2009), 'Income distribution and subjective happiness: A survey'. Social: OECD, Employment and Migration Working Papers, No. 96. Paris: OECD Publishing.

Shim, S., Xiao, J. J., Barber, B. L. and Lyons, A. C. (2009), 'Pathways to life success: A conceptual model of financial well-being for young adults', Journal of Applied Developmental Psychology, 30(6), 708-23.

Smith, S. (2015), Ending Global Poverty: A Guide to What Works. New York: St Martin's Press.

Ståhl, C. and MacEachen, E. (2020), 'Universal basic income as a policy response to COVID-19 and precarious employment: Potential impacts on rehabilitation and return-to-work', Journal of Occupational Rehabilitation, available at https://doi.org/ 10.1007/s10926-020-09923-w (accessed 9 December 2020).

Summerville, A. and Roese, N. J. (2008), 'Dare to compare: Fact-based versus simulation-based comparison in daily life', Journal of Experimental Social Psychology, 44(3), 664-71.

Swarbrick, M. and Yudof, J. (2015), Wellness in the 8 Dimensions, Collaborative Support Programs of New Jersey, Working Paper.

Van Parijs, P. and Vanderborght, Y. (2017), Basic Income: A Radical Proposal for a Free Society and a Sane Economy. Cambridge, MA: Harvard University Press.

Van Praag, B. M. S., Frijters, P. and Ferrer-i-Carbonell, A. (2003), 'The anatomy of subjective well-being', Journal of Economic Behavior and Organization, 51(1), 29-49.

Veenhoven, R. (2002), Why Social Policy Needs Subjective Indicators, Social Indicators Research, 58(1-3), 33-46.

Vosloo, W., Fouche, J. and Barnard, J. (2014), 'The relationship between financial efficacy, satisfaction with remuneration and personal financial well-being', International Business and Economics Research Journal, 13(6), 1455-70.

Willis, L. E. (2011), 'The financial education fallacy', American Economic Review, 101(3), 429-34.

Winkelmann, L. and Winkelmann, R. (1998), 'Why are the unemployed so unhappy? Evidence from panel data', Economica, 65(257), 1-15. 
Winkelmann, R. (2009), 'Unemployment, social capital, and subjective well-being', Journal of Happiness Studies, 10(4), 421-30.

World Health Organization (WHO), (2008), Closing the Gap in a Generation: Health Equity through Action on the Social Determinants of Health, Final Report of the Commission on Social Determinants of Health. Geneva: WHO.

Xiao, J. and Noring, F. (1994), 'Perceived saving motives and hierarchical financial needs', Journal of Financial Counseling and Planning, 5(1), 25-44.

Zyphur, M. J., Li, W. D., Zhang, Z., Arvey, R. D. and Barsky, A. P. (2015), 'Income, personality, and subjective financial well-being: The role of gender in their genetic and environmental relationships', Frontiers in Psychology, 6, 1493. 